\title{
Újszerű megközelítés: pontozáson alapuló, testmozgást ösztönző módszer - cikkismertetés
}

\author{
Points-based physical activity: a novel approach to facilitate changes in \\ body composition in inactive women with overweight and obesity - \\ paper review
}

Ismerteti: Hanzel Adrienn $\square$

Pécsi Tudományegyetem, Általános Orvostudományi Kar, Orvosi Népegészségtani Intézet

Szerzők: Adrian Holliday, Alice Burgin, Elyzabeth Vargas Fernandez, Sally A. M. Fenton, Frank Thielecke, Andrew K. Blannin

Megjelenés: BMC Public Health. 2018 Feb 17;18(1):261. doi: 10.1186/s12889-018-5125-2.

Beküldve: 2018. 05. 09.

doi: 10.24365/ef.v59i3.302

Kulcsszavak: inaktivitás, mozgás, testtömeg, táplálékbevitel

Keywords: inactivity, exercise, body weight, food intake

\section{BEVEZETÉS}

A közelmúltban végzett vizsgálatok arra hívják fel a figyelmet, hogy a középkorú nők két alapvető dolog miatt nem végeznek fizikai aktivitást: egyrészt az idő hiánya miatt, másrészt a motiváció hiánya miatt. Ezért a szerzők úgy gondolták, hogy ki kellene dolgozni egy olyan technikát, amely beleilleszthető a mindennapi életbe.

A kutatás célja az volt, hogy megvizsgálják, a túlsúlyos vagy elhízott, inaktív nők körében milyen hatásai vannak a fizikai aktivitás új, „pontozás alapú" (PBPA) motivációs módszerének a testöszszetételre, összehasonlítva a strukturált testmozgást végzőkkel.

\section{MÓDSZEREK}

Hetvenhat, túlsúlyos vagy elhízott, középkorú, inaktív nőt (41 \pm 2 év; átlagos BMI 29,2 \pm 3,4 $\mathrm{kg} / \mathrm{m}^{2}$ ) véletlenszerüen osztottak be három csoportba, 24 hetes vizsgálati időszakra. Az egyik csoport a „pontozás alapú” fizikai aktivitást végzőkből állt, nekik hetente 30 pontot kellett összegyújteniük a mozgással, a másik csoportot a strukturált testmozgást végzők képezték, akik heti 5-ször 30 percet töltöttek mérsékelt intenzitású testmozgással, harmadikként pedig a kontrollcsoport tagjai továbbra is a szokásos inaktív életmódot folytatták.

A PBPA-csoportba tartozó személyeket egy táblázattal látták el, amelyben különböző tevékenységeket tüntettek fel, például: porszívózás, kertészkedés, ablaktisztítás, vasalás stb. Mindegyik tevékenységhez tartozott egy tíz percnyi aktivitásra vonatkozó pontszám. A fizikai aktivitás pontszámait a metabolikus egyenértékből (MET) adaptálták, amelynek alapján 30 pont egyenértékű volt 150 percnyi tempós gyaloglással. A 0., 4., 12. és 24. héten testösszetételt (DXA: dual energy X-ray absorptiometry) és antropometriai paramétereket 
mértek. A saját bevalláson alapuló tevékenységeket heti rendszerességgel rögzítették. A 0. és a 24. héten a táplálkozást önbevallással (táplálkozási napló), a fizikai aktivitást objektív aktivitásmérő műszerrel (akcelerométer) adták meg.

\section{EREDMÉNYEK}

A 76 résztvevőből 58 fő teljesítette a 24 hetes intervenciós időszakot, innen származtak az elsődleges végpontokra vonatkozó adatok (testösszetétel, antropometria). A fizikai aktivitás objektív mérésére 19 résztvevőnél volt lehetőség, és 41 főnél vettek fel élelmiszerfogyasztásra vonatkozó adatokat.

A PBPA-csoportba tartozó nők szignifikáns súlycsökkenést értek el a 24 . hét végére: $-3,3 \pm 5,9 \mathrm{~kg}$ $(-3,4 \pm 7,1 \%, p=0,004)$. A derékbőség $(-2,8 \pm 4,6$ cm vs. $+2,1 \pm 6,6 \mathrm{~cm}, p=0,024)$, valamint a testzsír mennyisége $(-2,3 \pm 4,6 \mathrm{~kg}$ vs. $+0,1 \pm 2,0 \mathrm{~kg}$, $p=0,075)$ a PBPA-csoportban a 24. hét végére csökkent, szemben a kontrollcsoport értékeivel. A hasi lokalizációjú elhízás mind a 12. héten (-6,1 \pm
$12,6 \%, p=0,005)$, mind a 24 . héten $(-10,1 \pm 18,4 \%$, $p=0,005)$ csökkent a PBPA-csoportban, a visceralis zsírszövet pedig még nagyobb mértékű csökkenést mutatott $(-5,8 \pm 26,0 \%)$ szemben a kontrollcsoporttal $(+7,8 \pm 18,3 \%, p=0,053)$ a 24 . hét végére. A testösszetétel, a testtömeg és a derékbőség változatlanok voltak a strukturált testmozgást végzőknél. A PBPA-csoportban nőtt a könnyű fizikai aktivitás végzése, ugyanakkor trendszerúen csökkent az ülő életmódot folytatók száma. Ráadásul a PBPA-csoportban a napi energiafelvétel csökkenésének tendenciája is megfigyelhető volt $(-445 \pm$ $564 \mathrm{kcal} ; p=0,074)$, és jelentős kevesbedést tapasztaltak a napi zsírbevitel mennyiségében is $(p=0,042)$.

\section{KÖVETKEZTETÉS}

Az egyszerű ösztönzésen alapuló, fizikai aktivitást támogató új pontrendszer hatékony stratégiának tûnik a testtömeg és a testzsír csökkentésére a túlsúlyos és elhízott inaktív nőknél, szemben akár a strukturált testmozgást végzőkkel is.

\section{TANULSÁGOK A HAZAI SZAKEMBEREK SZÁMÁRA}

A szerző́k által ismertetett módszer könnyen beilleszthető a mindennapi rutinba, ezáltal nagyobb rugalmasságot és színesebb, teljesít-hetőbb választási lehetőséget biztosít a célpo-pulációnak. A vizsgálat eredményei az egész-ségügyben dolgozó szakemberek számára is fontos népegészségügyi üzenetet hordoznak, amely a lakosság tájékoztatásával jelentős mértékben hozzájárulhat az egészség javitá-sához, megőrzéséhez. 